\title{
Decentralization by Devolution Policy in Tanzania: Does Devolution Policy Improved Political Accountability?
}

\author{
Mpawenimana Abdallah Saidi, Robert Renatus Bujiku, Neilson Ilan Mersat, Arnold Puyok
}

\begin{abstract}
The aim of this study was to examine how decentralization by devolution policy improved situation of political accountability in governance system in Tanzania for a decade ago. The study conducted in the mainland Tanzania where by three regions of Mwanza, Geita and Kagera were involved in the study. Qualitative method and approaches were used to generate qualitative data from individual interviews involving Village chairpersons, Councilors, and Members of Parliament. Relevant different existing documents were critically reviewed and adopted. The sample size and the selection procedure of the key informants were purposively done, and snowball quota sampling was employed to reach the key study informants. A total of thirty (30) participants were carefully selected to participate in the study. The findings show that decentralization by devolution policy appeared to create awareness of accountability practice amongst politically elected leaders, even though it has not yet improved accountability practice in governance systems. Therefore, the study commends the overhaul of political accountability system in decentralized governance operations, this will help the government to restructure and reinforce implementation of political accountability.
\end{abstract}

Keywords: Decentralization, Accountability, Political accountability, Devolution policy

\section{INTRODUCTION}

Decentralization by devolution policy has incepted globally as a governance policy strategy to increase government responsiveness to citizens' needs, improve the effectiveness of the allocation public goods, mobilize citizens through new venues of local participation, increases accountability, and generally improves democracy from the lower level to the higher level of the government system (Bardan and Mookherjee 2006; Blair 2000; Daughters and Harper 2007).

Revised Manuscript Received on June 22, 2019

Mpawenimana Abdallah Saidi, Faculty of Social Sciences, Universiti Malaysia Sarawak (UNIMAS), Sarawak, Malaysia,

Robert Renatus Bujiku, Faculty of Social Sciences, Universiti Malaysia Sarawak (UNIMAS), Sarawak, Malaysia

Neilson Ilan Mersat, Faculty of Social Sciences, Universiti Malaysia Sarawak (UNIMAS), Sarawak, Malaysia

Arnold Puyok, Faculty of Social Sciences, Universiti Malaysia Sarawak (UNIMAS), Sarawak, Malaysia
For instance, African countries have undertaken reforms in the field of organization of the state and public life, particularly by adopting decentralization policy in the view of enhancing accountability and good governance (Ahmad, Devarajan, Khemani, \& Shah, 2005; Escobar-Lemmon \& Ross, 2013). While in Europe decentralization policy reforms are concerned with strengthening the municipal and inter-municipal framework, increase of accountability on public fund, a trend to regionalization, and the problems related to organizing urban areas (Minas, Wright \& van Berkel, 2012). Similarly, in North America, higher-level governments decentralization have shifted more of the accountability for financing activities to the local level, often cutting back on fiscal support from above (Peterson, 1997). In the same way, in Asia-Pacific, Indonesia, the Philippines, and India provide the most vivid examples of major decentralization reform for enhanced local government autonomy (Agrawal, 1999). Countries such as China and Vietnam have adopted decentralization strategies within the context of strongly centralized political ruling systems (Zhang, 2008).

Despite existing examples in western and eastern countries about the impact of $\mathrm{D}$ by $\mathrm{D}$ policy on accountability practice, previous studies have slightly failed to fully examine Tanzanian's situation of D by D policy influence on political accountability. The decentralization by devolution policy was anticipated to have improved political accountability in Tanzania; however, the lack of accountability remained to be a fundamental problem that affects all levels of decentralized governance authorities in the course of effective provision of service to the community.

The situation of lack of accountability amongst politically elected leaders in Tanzania, not only jeopardizing the good practice of decentralized form of governance, but also denies citizens right to hold into account their leaders (Venugopal \& Yilmaz, 2010). In the recent decades, essentially from 2010 to date, studies (Mollel,2010; Killian, 2017; Venugopal \& Yilmaz, 2010) indicate that there have been a rapid increase number of reported grand corruptions, politics of patronage and misuse of public fund, meanwhile the offenders under the umbrella of partisanship maintained their political positions without being held to account. Such disregard to accountability practice by political actors not only affects sectoral services across the country but also escalate a state of disappointment towards good governance initiatives.

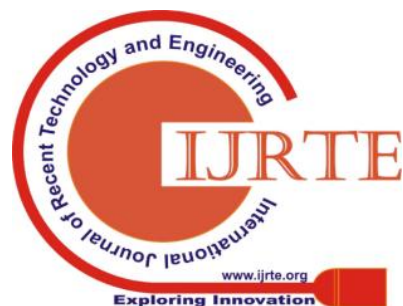


The complaints about accountability in the decentralized system have been reported through various political and civil society platforms.

Currently, it is exciting that decentralization by devolution as a government policy strategy; it is used to speed up development at local tiers; though to some extent, it seemingly denying fully autonomy to local authorities that would use it to discipline unaccountable leaders. Even though, there have been a fraction of distinctive studies in Tanzania on decentralization by devolution policy (Venugopal \& Yilmaz, 2010; Kessy \& McCourt,2013) within the government institutions, it is fundamentally unspecified if decentralization by devolution policy reform in Tanzania has improved political accountability in governance system. This study endeavors to fill this gap. Besides, it would contribute greatly to the political forum and academic discussion on how government political actors are implementing political accountability within the context of the ongoing decentralization by devolution in Tanzania.

\section{OBJECTIVES}

- To provide a broad view of political accountability practice in relation to decentralization by devolution policy

- To make recommendation based on current situation of political accountability through decentralization by devolution policy.

\section{LITERATURE REVIEW}

\section{Conceptualizing Decentralization}

Since inception of decentralization policy in human political governance, the term "decentralization" has been defined by different scholars. According to Manor (2011), decentralization refers to the redistribution of power within the state between the central government and other public authorities. Moreover, scholars (Conyers, 1981; Prud'homme, (1994) describe "decentralization as any transfer of powers or functions of government from national level to any sub-national level". In other words, it means that the powers or authority transferred to other authorities embrace a certain amount of autonomy that can be exercised by that particular decentralized level. Generally, scholars (Pollitt et al., 1998, McGinn \& Street, 1986; Vrangbæk, 2007; Prud'homme, 1994) appear to come to an understanding that "decentralization" can be conceptualized as a democratic practice of shifting autonomy, devolving powers and authorities, resources and responsibilities to lower levels of communities so as to permit them to make decisions and be accountable on matters affecting their governance affairs. This nature of looking at decentralization as a transfer of powers and authority in all forms of governance practices, not only inform us about the concept itself but also it gives us an opportunity to further explore the dynamic forms of decentralization as discussed below.

\section{Forms of Decentralization}

The central focus of integrating forms of decentralization in this paper is just to show the link between the forms and accountability practice. Traditionally, forms of decentralization referred to pragmatic features used to shift powers and authority from central government to local level of governments (Bagaka, 2008). According to Rondinelli, McCullough, \& Johnson, (1989) the most repeatedly utilized types of decentralization are the delegation, concentration, and devolution. Briefly, the study interested to discuss the following three major types of decentralization.

\section{Deconcetration}

Deconcetration is the term referring to the transfer of administrative responsibility for specified functions to lower levels of the central government bureaucracy, generally on some spatial basis (Ferguson and Chandrasekharan, 2004). The focus of deconcentration is to redistributes decisionmaking authority, financial and management responsibility among levels of the central government. It may involve only a shift of responsibilities from central service officials of the capital city to those stationed in provinces, districts (Gregersen, 2004). In real sense, deconcentration attempts to supervise responsibility of authority between levels of government since the role of holding actors into account remains in the hands of the central government.

\section{Delegation}

Delegation is the assignment of any responsibility or authority to another person (normally from a manager to a subordinate) to carry out specific activities (Bass \& Avolio, 1994). Similarly, Delegation means the passing of authority by one person who is at a superior position to someone else who is subordinate to him (Leana, C. R. (1987). The fundamental subject of delegation is to make the central government responsible for decision-making and administration of public functions to semi-autonomous organizations not wholly controlled by the central government, but ultimately accountable to it (Santiso, 2001). This type of decentralization provides a certain level of discretion in decision-making that may be exercised by an institution or individuals in the governance system. That means the institution or delegated person is accountable to the delegator.

\section{Devolution}

Devolution refers to the transfer of powers and responsibilities for governing purposes, which aiming at the creation or strengthening, financially and legally of local units of governments, whose activities are substantially outside of the direct control of central (Chandler, 2013). The focus on political devolution is to transfer authority for decision-making, finance, and management to semiautonomous units of local government with corporate status (World Bank, 2001). Furthermore, in the course of political institutions, devolution usually transfers responsibilities for services to municipalities that elect their own mayors and councils, raise their own revenues, and have independent authority to make investment decisions (Rondinelli, 1989). It is this type of administrative decentralization that underlies most political decentralization (Samoff, 1990). Therefore, in a devolved system, local governments have clear and legally recognized geographical boundaries over

\section{Published By:}


which they exercise authority and within which they perform public functions. Generally, the central theme of deconcentration, delegation, and devolution is the transfer of authorities, functions, rights, duties, powers and accountability of the top level management to the middle or low-level management. Thus, it can be established that devolution, deconcentration and delegation embrace an accountability role in the process of decentralization.

\section{Political Decentralization}

It is an interest of this study to underscore the essence of political decentralization and how it influences political accountability. Political decentralization refers to the transfer of autonomous, powers and authority that are obtained politically and moderate them from the central government to local governments (Falleti, 2005). Similarly, Blair (2000) refers political decentralization to democratic shift of power to local units of administration that are open and accountable to local citizens, who appreciate full political rights and freedom. The essential goal of political decentralization is to build the skill of local political units, which can be a national support in basic leadership and an opportunity for decision making on the matter of their essential concern at local level (Gaventa \& Valderrama, 1999). Thus, the positive feature of political decentralization is that it can revitalize political participation of both political representative and citizens and enhance accountability on the part of governing bodies by expanding information flows and interactions.

\section{Political Accountability}

Political accountability is the accountability of the politicians and public servants to the community and legislative bodies such a judiciary, full council meeting, a parliament or any other mandated accountability framework (Mulgan, 2000; Bovens, 2007). Similarly, political accountability is that politicians owed by elected politicians to the public for representing the community. Specifically, this means that the elected politicians are accountable for political representativeness and for their political integrity and political capability while in office (Przeworski, Stokes \& Manin, 1999; Richardson, 2000).

Likewise, political accountability is an unequal relationship between accounting and accountable parties in which, on the one hand, the accountable party is obliged to give an account of something to the accounting party and on the other hand, the accounting party exercises oversight over the accountable party (or, alternatively, the accountable party is obliged to receive oversight) (Day \& Klein 1987). Furthermore, political accountability may be regarded as political answerability of an individual with authority or power on actions or decision he/she has taken (Bovens, 2005). Indeed, political accountability is the innermost to political science, because the relationship between the policy makers and service providers is arguably the most significant factor that determines the abilities and incentives of governments to undertake actions on behalf of their citizens (Bovens, M. (2007).

Pragmatically, on the other hand, Przeworski, Stockes and Manin (1999) pointed out that to understand the problem of accountability we must consider again politicians or representatives' objectives. Elected representative may want to pursue their own ideas even if these differ from the citizens (Pitkin, 1967). Thus, it is significant to evaluate how practically accountability is put into practice for betterment of the community.

\section{Theoretical framework}

\section{Decentralization Theories and Conception of Accountability}

Theorization of decentralization policy has attracted different epistemological and ontological understanding on how decentralization may influence accountability in governance system (Faguet, 1997; Faguet, 2000; Fisman \& Gatti, 2002). Moreover, Scholars (Prud'Homme, 1995; Garman, Haggard \& Willis, 2001; Falleti, 2005) not only from western and eastern democratic governance civilizations but also the entire of African continent have been attempting to develop their own understanding towards decentralization. Nevertheless, much of reformists decentralization arguments which has been adopted in this study is that decentralization brings powers and authorities near to the people who actually profit from participating further enthusiastically in actions and decision making in their devolved governments (Rondinelli, 1981; Prud'Homme, 1995). This nature of involvement and participation of people in governance operations not only creates a sense of ownership of these authorities but also contributes to enhance political accountability of representative entrusted for service provision in the community. Essentially, it is true that with devolved government, political accountability practice can easily be monitored closely by people in that particular political premises, especially if people are empowered to hold politicians into account. Another optimistic argument which is embedded in decentralization theories is that decentralization by devolution contributes to benchmarks of good governance (Grindle, 2007). It is by shifting powers and authorities, particularly democratic fully autonomy, the subnational levels enjoy the power and authorities to decide on matters affecting their governance and political accountability affairs (Bellamy, Castiglione, Follesdal \& Weale, 2011). Thus, the central focus with good governance is that the fully authority and powers devolved to subnational levels are anticipated to contribute to confidences of holding into account local actors.

\section{METHODOLOGY}

The current research paper has focused on qualitative method for analyzing the reality of political accountability practices in the course of implementing decentralization by devolution policy in the selected areas. The sample size and the selection procedure of the key informants (males and females) were purposively done, and snowball quota sampling was employed to reach the key study informants. A total of thirty (30) participants were carefully selected to participate in the study. 
Besides, a semi-structured-interview was used a source of data collection that comprised of questions followed by optional answers. The interview guide consisted of different types of questions such as demographic information of respondents followed by the relevant about the situation of political accountability practice in decentralization by devolution policy implementation. Additionally, ethical consideration was highly taken in to account during and after the course of data collection exercise. The in-depth interviews were documented, transcribed, and thematically analyzed.

\section{Demographic backgrounds of the respondents}

The tables below briefly present the demographic and social characteristics of In-depth Interview Participants. The study sample comprised of 30 men and women who were recruited through snowball sampling. The study was carried out through that broken sample as shown in the table below. The demographic characteristics of participants of this study reveals that the majority of participants of this study were male followed by female. The reason behind of male dominance in this study is that they are majority politically elected in most study areas. As a result, it was important to consider their participation in this study. Additionally, most of the informants were between the age ranges of $36-50$, followed by those within the group of $18-35$. Besides, educational wise, the study revealed that majority of informants were secondary school graduates. Some of this background information has been used in the next section to illustrate the views and opinions of the participants.

Table. 1 Politically Elected Leaders

\begin{tabular}{cccc}
\hline Region & Village Chairpersons & Councilors & Members of Parliament \\
\hline Mwanza & 4 & 4 & 2 \\
Geita & 5 & 4 & 1 \\
Kagera & 4 & 4 & 2 \\
\hline Total & 13 & 12 & 5 \\
\hline
\end{tabular}

Source: Field Work, 2018

Table. 2 Demographic and Social Characteristics of In-depth Interview Participants

\begin{tabular}{|c|c|c|}
\hline Demographic characteristics & Number of & Percentage \\
\hline \multicolumn{3}{|c|}{ respondents } \\
\hline Gender: & & \\
\hline Male & 18 & 60 \\
\hline Female & 12 & 40 \\
\hline Total & 30 & 100 \\
\hline \multicolumn{3}{|l|}{ Age } \\
\hline $18-35$ & 6 & 20 \\
\hline $36-50$ & 20 & 67 \\
\hline $51-70$ & 4 & 13 \\
\hline $71+$ & 0 & 0 \\
\hline Total & 30 & 100 \\
\hline \multicolumn{3}{|l|}{ Education } \\
\hline Non-schooling & 0 & 0 \\
\hline Primary & 4 & 13 \\
\hline Secondary & 17 & 57 \\
\hline High school & 2 & 7 \\
\hline Diploma & 3 & 10 \\
\hline University degree & 4 & 13 \\
\hline Total & 30 & 100 \\
\hline \multicolumn{3}{|l|}{ Occupation } \\
\hline Village chairperson & 13 & 43 \\
\hline Councilor & 12 & 40 \\
\hline Member of Parliament & 5 & 17 \\
\hline Total & 30 & 100 \\
\hline
\end{tabular}

Source: Field data (2018) 


\section{RESULTS AND DISCUSSION}

The findings of the study revealed that decentralization by devolution policy to some extent has created a sense of accountability awareness amongst politically elected leaders in governance systems; however, it appears to have not yet improved accountability practices in some leaders in selected regions in Tanzania. The situation of accountability in $\mathrm{D}$ by $\mathrm{D}$ policy, it is here thematically analyzed and carefully presented through selected quotes made by participants.

During the study, it was interesting to find out that even the current leaders themselves have experienced the same accountability challenge in governance systems. From their point of view and experience, they acknowledged realizing how impractical accountability in decentralized government is. From their experience, education background and political career, they recognized to have seen the beauty of D by D policy; however, the lack of accountability has made the policy irrelevant in the promotion of good governance.

"In reality, the inception of decentralization by devolution has only created awareness of how local government can behave as semi-autonomy governments; however, it has not yet improved accountability at all." (55 years old, Councilor).

It can be noted that in the view of this particular current Councilor, decentralization by devolution has created the level of awareness of political accountability practice at his level. Though, it was observed that the challenge rests in the attitudinal mind of people on how to implement political accountability. Similar views and opinions were also noted in the quotes as illustrated by the following participants below:

"Basically, to me, this policy has a little impact on accountability practice of government leaders, as you know, I'm the Ex-MP from the ruling party, and to be honesty, and decentralization by devolution policy has made local governments to realize their potentials only. There are a lot of mis use of public resources, particularly monetary resource of which people who chop the government money are not ready to be held accountable" (51 years old, Member of Parliament)

"This government has many impractical policies, I'm not sure if this D by D policy has any impact on accountability of individual leaders because we see ourselves how these political leaders are reluctant to be held accountable. Actually, the good thing is that the central government has recognized an importance of our lower level governments. (48 years old, Village Chairperson)

The inception of D by D policy in Tanzania, among other reasons of its inception, was to increase a chance of citizens to hold into account government leaders. The policy has more than 30 years now; it is the policy that was anticipated to have accountability impact on government officials as illustrated by the following ex-official. This participant who actually is a retired government official, had similar views as specified above, even though he stated in a different way. To him the D by D policy sounded as a practice that could pragmatically influence accountability practice if there could be enough social awareness. Similar findings were also found in the study conducted by Mollel (2010) on reality of decentralization in Tanzania. This participant presented his doubtful perception; as he specified that accountability practice in decentralized government is highly affected negative attitude by government actors, as they see it as a punishment rather than an initiative aimed at improving good governance. In the in-depth interview, he illustrated that:

"Since I'm out of the governance system for a good number of years now, what I can assure you is that, decentralization by devolution policy it was incepted in our days, purposively to enhance accountability at local levels and other levels of government. However, in the recent time, things are not going well despite of awareness. I think, you know that there are complaints about lack of accountability everywhere in this country. You visited me at right time. I think, may be your study will create awareness, however, it is time for citizens of this country to seriously address this matter." (53 years old, Member of Parliament)

It is interesting to note that even ordinary citizens they had the same fear that decentralization by devolution policy which has been promoted for many years it has proved failure in regard to accountability practice of government leaders. It was observed that citizens have been using public meeting to show their concern about lack of accountability among government officials. The lack of accountability denied citizens equitable and effective delivery of services in their localities. One of these ordinary citizens commented that:

"... it is by force; otherwise none of government official is voluntarily ready to quit his or her position in regard to accountability obligation. It is one thing to decentralize the government, and to have people accountable. Actually, D by D created awareness, though, there is no accountability." (36 years old, Village Chairperson)

"let me tell you the truth...the central government has decentralized but it has retained the powers of holding public officials into account, that why there is no effective accountability. Traditionally, when a public official offends, the government pretends to transfer or sends off that particular offender to other places" (43 years old, Councilor)

In very interesting and special way, one of participants had contrary contribution on this particular subject. In his opinions hesitated that, lately there has emerged a growing debate in Tanzania about emerging centralization instead of decentralization by devolution as it has been advocated for many years. Such sentiments were revealed to show how D by $\mathrm{D}$ policy has failed to promote accountability that why the government, behind closed doors started to re-claim its powers from decentralized governments. This participant was suspicious about sustainability of existing devolved governments. In his views about D by D policy, he stated that "public official they are obliged to respect accountability practice". Related findings were also found in the study conducted by Marcossy (2014) on social accountability monitoring and the civil society organizations in Tanzania.

This participant demonstrated his broad concern about absence of accountability in governance systems. In his opinions, he lamented that:

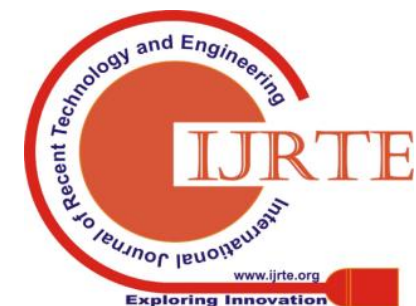


"The government should seriously address accountability matter without delay. This D by D policy is nothing without accountability, as local investor; I know what you are trying to find out. I tell you, the awareness is there, but people are not committed to accountability practice that why there is ineffective and inefficiency in the performance of the government. I think it is high time for the government to review the policy and strengthen accountability framework" (37 years old, Member of Parliament)

Considering participants' responses on how decentralization by devolution policy has improved political accountability, the findings shows that $\mathrm{D}$ by $\mathrm{D}$ policy is an instrument that can facilitate implementation of accountability if it is positively perceived by government officials. Previous researches (Max and John (1991; Mollel, 2010; Venugopal \& Yilmaz, 2010; Mgonja \& Tundui, 2012) indicate that decentralization by devolution policy has always been linked with the promotion of good governance at subnational level. During the study it was observed that majority of participants acknowledged and appreciated the inception of D by D policy in their areas. However, their concern was about the lack of political accountability in this particular governance policy. In their views, they happened to appreciate the beauty of the policy though they casted a lot of complaints on negative attitude prevailing in the mind of majority public officials about political accountability practices. Some of participants complained against the central government to have maintained its autonomy in spite of devolution as result there have been regular interception by the central government in decision related to political accountability of representatives. Related views was noted in a study by Semboja, Joseph \& Therkildsen (1991) who found out that the central government in Tanzania had been interrupting the deliberations or decisions made by local authorities by holding back the implementation of deliberations. This means that in one way or another central government plays an important role in positive or negative practice of accountability. Thus, the failure to control emerging negative accountability attitude by politicians and interruption by the central government to subnational decisions appears to water down the $\mathrm{D}$ by $\mathrm{D}$ policy in selected areas.

\section{CONCLUSION}

The findings of this study justifies that the Tanzanian's current situation of D by D policy appears to have a slight positive impact on accountability awareness. However, in practice, the $\mathrm{D}$ by $\mathrm{D}$ policy has registered insignificant improvement in regard to political accountability practice of politicians in the selected research areas. The failure attributed by a negative attitude developed by politicians about accountability practices. Furthermore, the study discovered that there has been a regular interruption by the central government to subnational governments particularly in matters related to political accountability. During the study it was observed that some offenders who were supposed to be held to account were transferred from one area to another in order to hide their messes. This was perceived by some of the participants of this study as the

failure of $\mathrm{D}$ by $\mathrm{D}$ policy in regard to effective political accountability policy. Similarly, the study to some extent coincides with other previous studies (Mwakagenda, 2013; Killian, 2017) conducted in other areas in Tanzania where it was found that there was a certain degree of awareness created by decentralization policy in relation to social accountability (Marcossy, A.M. (2017). In spite of the fact that $\mathrm{D}$ by $\mathrm{D}$ among other reasons was intended to promote accountability, the study observed that there was deliberate lack of accountability amongst public officials.

The findings of this study have significant implication for policy makers and public officials. For policy makers it is their duty to review by overhauling the $\mathrm{D}$ by $\mathrm{D}$ policy particularly in the area related to political accountability practice. Also, for politicians is high time to change attitude towards accountability practice by recognizing and promote good governance in their decentralized authorities.

\section{REFERENCES}

1. Agrawal, A. (1999). Accountability in Decentralization: A framework with South Asian and West African cases. The Journal of Developing Areas, 33(4), 473-502.

2. Ahmad, J., Devarajan, S., Khemani, S., \& Shah, S. (2005) Decentralization and Service Delivery. The World Bank.

3. Bagaka, O. (2008, October). Fiscal Decentralization in Kenya: The Constituency Development Fund and the Growth of Government. In Proceedings Of 20th Annual Conference Of The Association For Budgeting And Financial Management, Chicago.

4. Bardhan, P. and D. Mookherjee (2006) "Accountability and Decentralization of Infrastructure Delivery in Developing Countries". Economic Journal 116.

5. Bass, B. M., \& Avolio, B. J. (Eds.). (1994). Improving organizational effectiveness through transformational leadership. Sage.

6. Bellamy, R., Castiglione, D., Follesdal, A., \& Weale, A. (2011) Evaluating trustworthiness, representation and political accountability in new modes of governance. In New modes of governance in Europe (pp. 135-162). Palgrave Macmillan, London.

7. Blair, H. (2000). Participation and accountability at the periphery: democratic local governance in six countries. World development, 28(1), 21-39.

8. Bovens, M. (2007). Analysing and assessing accountability: A conceptual framework 1. European law journal, 13(4), 447-468.

9. Chaligha, A. (2008). Local Government and Citizen Participation in Tanzania: From a local government reform perspective. Dar es Salaam:

10. Chandler, J. A. (2013). New Labour. In explaining local government. Manchester University Press.

11. Conyers, D. (1981). Decentralization for regional development: A comparative study of Tanzania, Zambia and Papua New Guinea. Public Administration and Development, 1, 107-120

12. Escobar-Lemmon, M., \& Ross, A. D. (2013). Does decentralization improve perceptions of accountability? Attitudinal evidence from Colombia. American Journal of Political Science, 58(1), 175-188.

13. Faguet, J. P. (1997). Decentralization and local government performance. Food and Agriculture Organization.

14. Faguet, J. P. (2000). Decentralization and Local Government Performance: Improving Public Services Provision in Bolivia. Revista de Economía Del Rosario, 3(1).

15. Falleti, T. G. (2005). A sequential theory of decentralization: Latin American cases in comparative perspective. American Political Science Review, 99(3), 327-346.

16. Falleti, T. G. (2010). Decentralization and subnational politics in Latin America. Cambridge University Press.

17. Ferguson, I., \& Chandrasekharan, C. (2005). Paths and pitfalls of decentralization for sustainable forest management: experiences of the Asia-Pacific region. The Politics of Decentralization: Forests, Power and People, 63-85.

18. Fisman, R., \& Gatti, R. (2002). Decentralization and corruption evidence across countries. Journal of Public Economics, 83(3), 325-345. 
19. Garman, C., Haggard, S., \& Willis, E. (2001). Fiscal decentralization: A political theory with Latin American cases. World Politics, 53(2), 205-236.

20. Gaventa, J., \& Valderrama, C. (1999, June). Participation, citizenship and local governance. In Background note for the workshop "Strengthening Participation in Local Governance," University of Sussex, Institute of Development Studies (Vol. 21).

21. Gregersen, H. M., Contreras-Hermosilla, A., White, A., \& Phillips, L. (2005). Forest governance in federal systems: An overview of experiences and implications for decentralization. The Politics of Decentralization. Forests, People and Power. Earthscan, Sterling, London, 13-31.

22. Grindle, M. S. (2007). Going local: decentralization, democratization, and the promise of good governance. Princeton University Press.

23. Kessy, A. T., \& McCourt, W. (2013). Is decentralization still recentralization? The local government reform programme in Tanzania. In Public Sector Reform in Developing and Transitional Countries (pp. 115-123). Routledge.

24. Killian, B. (2017). The Ups and Downs of Popular Demands for Accountability in Tanzania. The African Review, 36(1 \& 2), 23-44

25. Klein, R., \& Day, P. (1987). Accountabilities: five public services. London: Tavistock.

26. Leana, C. R. (1987). Power relinquishment versus power sharing: Theoretical clarification and empirical comparison of delegation and participation. Journal of Applied Psychology, 72(2), 228.

27. Manor, J. (2011). Perspectives on decentralization. International Center for Local Government (ICLD) Working Paper, (3).

28. Marcossy, A. (2014). A paper published in the Journal of Tanzania Public Sector Management Journal, Vol III Number 2, (p 24 - 42).

29. Marcossy, A.M. (2013). The linkage between social accountability and poverty in Local government Authorities in Tanzania. Journal of public Service Management (4): 24-27.

30. Marcossy, A.M. (2017). Why is Tanzania poor? The Role of Social Accountability in Poverty Reduction.

31. McGinn, N., \& Street, S. (1986). Educational decentralization: Weak state or strong state? Comparative Education Review, 30(4), 471-490.

32. Mgonja, B. E., \& Tundui, C. (2012). Institutional Impacts of the Local Government Reform Program on Good Local Governance in Tanzania. International Journal of Academic Research in Business and Social Sciences, 2(5), 206.

33. Minas, R., Wright, S., \& van Berkel, R. (2012). Decentralization and centralization: Governing the activation of social assistance recipients in Europe. International Journal of Sociology and Social Policy, 32(5/6), 286-298

34. Mollel, H. A. (2010). Participation for local development: The reality of decentralization in Tanzania (p. 172). African Studies Centre Leiden.

35. Mulgan, R. (2000). 'Accountability': an ever-expanding concept? Public administration, 78(3), 555-573.

36. Mwakagenda, H.T. (2013). Social Accountability Monitoring in Africa: Public Expenditure Tracking Survey in Tanzania as a case study. The leadership Forum, Dar es Salaam, Tanzania. 22pp

37. Peterson, G. E. (1997). Decentralization in Latin America: learning through experience. The World Bank.

38. Pitkin, H. F. (1967). The concept of representation (Vol. 75). Univ of California Press.

39. Pollitt, C., Birchall, J., \& Putman, K. (1998). Decentralizing Public Service Management. London: MacMillan Press

40. Prud'homme, R. (1994). On the Dangers of Decentralization. Policy Research Paper 1252. Washington, DC: The World Bank.

41. Prud'Homme, R. (1995). The dangers of decentralization. The World Bank research observer, 10(2), 201-220.

42. Przeworski, A., Stokes, S. C., \& Manin, B. (Eds.). (1999). Democracy, accountability, and representation (Vol. 2). Cambridge University Press.

43. Richardson, R. (2000). Political accountability and public sector performance management: Exploring the linkages and lessons. In V International Congress of CLAD on State Public Administration Reform.

44. Rondinelli, D. A. (1981). Government decentralization in comparative perspective: theory and practice in developing countries. International review of administrative sciences, 47(2), 133-145.
45. Rondinelli, D. A., McCullough, J. S., \& Johnson, R. W. (1989). Analysing decentralization policies in developing countries: a political-economy framework. Development and change, 20(1), 57-87.

46. Samoff, J. (1990). Decentralization: The politics of interventionism. Development and Change, 21(3), 513-530.

47. Santiso, C. (2001). Good governance and aid effectiveness: The World Bank and conditionality. The Georgetown public policy review, 7(1), $1-22$.

48. Venugopal, V., \& Yilmaz, S. (2010). Decentralization in Tanzania: an assessment of local government discretion and accountability. Public Administration and Development, 30(3)

49. Vrangbæk, K. (2007). Decentralization in towards a typology fo decentralization in health care. In R.B. Saltman, V. Bankauskaite \& K Vrangbæk (Eds.), Decentralization in Health Care: Strategies and Outcomes (pp. 1-8).Maidenhead, Berkshire, UK: McGraw-Hill/Open University Press.

50. Zhang, J. (2008). Decentralization and Growth: China Context [J]. China Economic Quarterly, 1 